\title{
Land Consolidation at the Household Level in the Red River Delta, Vietnam
}

\author{
Thi Ha Thanh Nguyen ${ }^{1, *}$, Thi Quynh Nhu Thai ${ }^{2}$, Van Tuan Tran ${ }^{1}$, Thi Phin Pham ${ }^{1}$, \\ Quang Cuong Doan ${ }^{1}{ }^{1}$, Khac Hung Vu ${ }^{1}$, Huong Giang Doan ${ }^{3}$ and Quang Thanh Bui ${ }^{1}$ \\ 1 Faculty of Geography, VNU University of Science, No. 334 Nguyen Trai Street 120080, Thanh Xuan District, \\ Hanoi 100000, Vietnam; tranvantuan@hus.edu.vn (V.T.T.); phamthiphin@hus.edu.vn (T.P.P.); \\ doanquangcuong@hus.edu.vn (Q.C.D.); vukhachung@hus.edu.vn (K.H.V.); thanhbq@vnu.edu.vn (Q.T.B.) \\ 2 Institute of Research on Land Management, General Department of Land Administration, \\ No. 9/78 Giai Phong Road 116314, Dong Da District, Hanoi 100000, Vietnam; ttqnhu@gdla.gov.vn \\ 3 Faculty of Agriculture and Forestry, Tay Bac Univeristy 34155, Thành phố Sơn La 34000, Vietnam; \\ giangdh@utb.edu.vn \\ * Correspondence: hathanh-geog@vnu.edu.com; Tel.: +84-912-624-802
}

Received: 16 May 2020; Accepted: 9 June 2020; Published: 14 June 2020

\begin{abstract}
Land consolidation is an effective solution for the hindrances in agricultural production and rural development caused by land fragmentation. In the Red River Delta of Vietnam, where land is still highly fragmented, the application of land consolidation is required. By using a bottom-up approach, the paper aims to clarify the effect of land consolidation on farm households in selected communities (as case studies) of two provinces (Hung Yen and Vinh Phuc) in the Red River Delta. With the primary structured and semi-structured interview method, 172 household questionnaires and 22 in-depth questionnaires (from local officials) were collected. The results indicated that land consolidation could either change the spatial structure or expand the area of land parcels, facilitate the conversion of crop structure, increase household incomes, accelerate mechanization in agricultural production, and create more job opportunities for agricultural laborers. However, we also found that the land consolidation process conducted in the case studies is inadequate and lacks integration with other related policies.
\end{abstract}

Keywords: land consolidation; land fragmentation; Red River Delta

\section{Introduction}

Land consolidation policies are an essential tool needed by governments to develop rural areas sustainably, "especially in countries where rural property is highly fragmented" [1] (p. 463). Accordingly, the benefits of land consolidation are diverse, as proven in several studies, such as comprehensively changing the spatial structure of land use in rural areas [2], mitigating fragmentation [3], reducing average product costs [4], diminishing farm labor intensity [3], increasing crop productivity [5], enhancing the probability of using machinery and technologies in agricultural cultivation $[3,6]$, and protecting the environment and natural resources [7]. In Europe, the distribution of land is used as a criterion for either evaluating rural social-economic conditions or predicting the change in agricultural production and farmers' incomes [8].

Vietnam is a traditional agricultural country that has made significant progress in terms of agriculture as a result of the implementation of Doi Moi (Renovation) policies since 1986 [9]. Previously a starving country, Vietnam has currently achieved a high level of food output per capita among low middle-income countries [10]. Nonetheless, even after practicing land consolidation for a long time in the Doi Moi period, agricultural land in this country is still highly fragmented, with higher fragmentation levels than those of other countries in the same economic region, such as Cambodia, 
Myanmar, and the Philippines [11]. This issue has been investigated in the northern part of the country. For example, Tran Anh Tuan [12] focused on evaluating the effects of a land consolidation program in the Dong Long commune, Tien Hai District, and Thai Binh Province, and the author emphasized two kinds of effects: enlarging areas and reducing the numbers of paddy parcels and minimizing the travel time needed by village farmers to access their fields. Xuan Thi Thu Thao et al. [13] also assessed the impact of land consolidation on the land use of households in Nam Dinh Province. They concluded that for effective land use, each type of land use (such as two-crop paddy or aquaculture) requires a proper land area. P. Van Hung et al. [14] used various methods to conclude that fragmentation harmed crop productivity and increased family labor use and other production expenses. Meanwhile, research by Sally P. Marsh and T. Gordon MacAulay [15] concentrated more on the market of land transactions for land consolidation.

It is often difficult to apply a top-down approach in researching land consolidation, as leases and transfers of land use rights (LURs) between households often take place in the form of self-agreements, while formal procedures require more time and tax fees. The number of land transactions reported in local land materials has not been consistently counted [16]. Therefore, the study of land consolidation in the Red River Delta at the household level (i.e., a bottom-up approach) is the most suitable and feasible approach. This research aims to apply the bottom-up approach to clarify the multiple impacts of land consolidation on farm households in some selected communes of Hung Yen and Vinh Phuc Provinces in the Red River Delta. Some inadequacies of land consolidation that have not been addressed in the above studies are discussed in this research. This article is one of few studies about land consolidation conducted since several new policies on this issue were enacted in Vietnam. The results can contribute to decision-making regarding land consolidation policies in the Red River Delta or in other countries that have similar land policies.

\section{Land Consolidation and Policies}

\subsection{Around the World}

Comprehensive land consolidation by the FAO (Food and Agriculture Organization of the United Nations) is understood in a broad sense. It emphasizes not only parcel reallocation but also other measures used to promote rural development, such as constructing road networks, rehabilitating irrigation and drainage systems, erosion control, and environmental protection [17] Similarly, in Rwanda, land consolidation includes the choice of priority crops and proper cultivation modalities in the Crop Intensification Programme (CIP) [5]. In China, "land consolidation can be grouped into three classes: farmland consolidation, land exploitation, and land reclamation" [18].

Land consolidation processes have taken place all over the world for a long time, starting in Western Europe in the 1650s [19]. Some other regions have recently begun to consolidate agricultural land use, such as Central and Eastern Europe [7], China (1999) [20], Croatia (2000), Ukraine (2005) [21] (p. 54), and Rwanda (2008) [5]. These processes serve as a response policy of these nations to land fragmentation in agriculture, which results from different causes. In some European countries, the land privatization process has led to millions of households owning small land parcels, which are an average of 1 ha and divided into incontiguous parcels [7]. Meanwhile, in China, the reason for land fragmentation is the traditional egalitarian conceptions of land inheritance and equal land distribution for agricultural labor. People also prefer cultivating in parcels with different geographical conditions (topography, slope, and soil) to diversify crops and reduce risks from natural disasters [22]. In Albania, agricultural land fragmentation results from equal division by eligible persons and quality [23]. Even within the same country, the land fragmentation situation is heterogeneous due to the geographical conditions. In Galicia (Spain), the central area has larger agricultural land parcels but fewer parcels than in the coastal and southern regions, while the mountainous area usually has larger parcels than those in the valleys [24]. In China, the average number of parcels per household is higher in the west and lower in the east [22]. 
On the one hand, land fragmentation is useful for avoiding risks of crop failure due to natural disasters but is less useful for serving market orientation [23]. In addition, products cultivated from fragmented agricultural land will eventually experience a shortage due to the growing population [25] (p. 249). Therefore, land consolidation is conducted to "remove the defects in the agricultural structure" [25] (p. 249), and its additional goals include the increase of farmer's income and crop yields. During these recent years, in many European countries, land consolidation policies have tended to change from the original goal of agricultural growth to widespread rural development [24], thus having a broader and more far-reaching influence.

On the other hand, land consolidation policies are not always practical. Xiaobin Jin (2017) noted that, in poor soil in China, the effect of land consolidation projects was not apparent [18]. It also had less impact in areas that lacked investment in agricultural infrastructure [26]. In some places, land consolidation reduces only the number of parcels and changes the agricultural landscape, but it does not impact the number of landowners, as in Galicia [24]. Lacking community participation also leads to the failure of customary land consolidation in many sub-African countries [27].

Geographical, cultural, economic, and historical contexts, as well as various land management policies among different countries, have resulted in altered land consolidation regulations. In Rwanda, there was a land consolidation process exercised under the Organic Land Law, in which a farmer can maintain his/her land ownership, but they must respect regulations for land use consolidation, which is promulgated by the Ministry of Agriculture and Animal Resources, in a spatial zone of each kind of crop [28]. In China, people do not have the right to buy and sell agricultural land, but they can rent it. People in nonagricultural sectors tend to sublease their agricultural land. These regulations, in reality, have a modest impact on the reduction of land fragmentation [22]. In a developed country, such as Italy, financial support is one of the practical tools used by the state to consolidate and restructure land use, in addition to setting up law provisions to minimize land fragmentation [29].

\subsection{In Vietnam}

\subsubsection{National Policies}

In Vietnam, the Doi Moi period, which propelled Vietnam into a market-oriented economy, experienced several land reforms and transitions in land use policy. After the cooperative system was dismantled, agricultural land parcels were distributed equally to individual households based on geographical location and soil quality to mitigate rural poverty, as stipulated by Land Law 1993 and Decree 64/CP. In addition, people were empowered to use land when they were allowed to convert, transfer, lease, inherit, and mortgage their LURs. Additional rights to sublease and donate LURs to relatives and acquaintances were adopted through the 1998 amended Land Law; two other rights of LURs were added by the Land Law 2003: guarantees and contributing capitals with LURs. These changes resulted in the further fragmentation of agricultural land parcels [30]. However, this expansion of LURs favored the accumulation and concentration of land for individuals and enterprises from various sources.

Key national policies on these issues are shown in the Table 1. 
Table 1. Key national policies related to encouraging land consolidation in Vietnam during the Doi Moi period.

\begin{tabular}{|c|c|c|}
\hline Year of Issued & Name of Policy & Issued Content Related to Land Consolidation \\
\hline 1993 & Land Law 1993 [31] & $\begin{array}{l}\text { Land consolidation through land users exercising their rights: } \\
\text { conversion, transfer, lease, inheritance, and mortgage of LURs. }\end{array}$ \\
\hline 1998-1999 & $\begin{array}{l}\text { Resolution No. 06-BCT [32], } \\
\text { Directive No } \\
\text { 10/1998/CT-TTg [33], No. } \\
\text { 18/1999/CT-TTg [34] }\end{array}$ & $\begin{array}{l}\text { Encouraging local governments and the farmers to participate in } \\
\text { plan development and implementation of a program of } \\
\text { "Regrouping and rearranging of land parcels" to create larger fields } \\
\text { for agricultural production. }\end{array}$ \\
\hline 2000 & $\begin{array}{l}\text { Resolution No. } \\
\text { 03/2000/NQ-CP [35] }\end{array}$ & Encouraging the development of farm economics. \\
\hline 2002 & Decision 80/2002/QD-TTg [36] & $\begin{array}{l}\text { Directing the planning of zoning concentrated commodity } \\
\text { agricultural regions, favoring advantageous conditions for } \\
\text { producers and enterprises to organize agricultural production and } \\
\text { make contracts regarding selling commodity agricultural products. } \\
\text { This decision inspired the implementation of forming large fields. }\end{array}$ \\
\hline 2003 & Land Law 2003 [37] & $\begin{array}{l}\text { Expanding LURs for people: subleases, donations, guarantees and } \\
\text { capital contribution with LURs. }\end{array}$ \\
\hline 2008 & Resolution No 26/NQ/TW7 [38] & $\begin{array}{l}\text { Expanding the duration of LURs; encouraging and promoting } \\
\text { land consolidation. }\end{array}$ \\
\hline 2009 & Decision 491/QD-TTg [39] & $\begin{array}{l}\text { Promulgating the national criteria for building a new countryside, in } \\
\text { which land use planning and essential infrastructure for agricultural } \\
\text { development is the first criterion. Understanding this criterion, land } \\
\text { grouping and rearranging had been conducted in several localities. }\end{array}$ \\
\hline 2012 & Resolution No 19-NQ/TW [40] & $\begin{array}{l}\text { Allocating or leasing agricultural land to households and } \\
\text { individuals for a longer term than before. In addition, expanding } \\
\text { limited land area for LURs based on the specific conditions of each } \\
\text { region to enhance the process of land consolidation, gradually } \\
\text { forming large fields for agricultural commodity production. }\end{array}$ \\
\hline 2013 & Decision 62/2013/QD-TTg [41] & $\begin{array}{l}\text { Encouraging the development of cooperation, production linkage } \\
\text { with agricultural product consumption, and forming large fields. }\end{array}$ \\
\hline 2013 & Land Law 2013 [42] & $\begin{array}{l}\text { Households and individuals may transfer LURs no more than ten } \\
\text { times the agricultural land assignment quota, increasing the land } \\
\text { use term for the land cultivation of annual crops to } 50 \text { years. } \\
\text { Enterprises are considered by the State for land allocation or leases } \\
\text { based on an approved investment project. The State encourages } \\
\text { households and individuals to contribute capital by LURs to project } \\
\text { investors. }\end{array}$ \\
\hline 2018 & Decree 98/2018/ND-CP [43] & $\begin{array}{l}\text { Encouraging the development of cooperation and linkages in the } \\
\text { production and consumption of agricultural products, in which } \\
\text { rearranging fields and expanding the area of concentrated } \\
\text { agricultural production region is one of the necessary criteria for a } \\
\text { cooperation project. }\end{array}$ \\
\hline
\end{tabular}

After recognizing the problem of land fragmentation, especially since 1998, the Vietnamese government has made great efforts to promote land consolidation to develop agricultural commodity production using a variety of regulations, such as expanding limited land area per individual or enterprise and limited duration of LURs, encouraging farmers to produce on a large scale or engaging in farm economics (According to the Resolution No 03/2000/NQ-CP, farm economics is a form of commodity production in agriculture, mainly based on farm households, in order to expand the scale and improve production efficiency of cultivation, husbandry, aquaculture, and afforestation, as well as associate the production with the processing and market consumption [35].) to meet the market demand, expanding LURs, and encouraging the formation of large fields (According to the Decision 62/2013/QD-TTg in 2013, a large field is defined as "a form of production based on the co-operation between farmers and enterprises on a large scale to centralize farm products and increase quality and competitiveness" [41] (p. 202). The Circular 15/2014/BNN\&PTNT in 2014 also specified that the area of a large field is identified depending on the actual situation in agricultural land of each province [44]. The average area of a large field in Vietnam was about 256.1 ha (in 2016), and varied by kinds of land 
use and by regions [45].). These regulations, vis-à-vis typical supported policies in vocational training, occupational transition, and finance investment, have moved the country towards the comprehensive development of farmers, agriculture, and rural area.

In particular, together with the broad implementation of building new countryside (New countryside is a commune that meets 19 criteria (such as planning, socio-economic infrastructure (transportation, electricity, clean water, schools, rural markets, post offices, ... ), production modalities, poverty, social security, ... ) specified in Decision 491/QD-TTg in 2009 [39].) over the country since Decision 491/QD-TTg (2009), land regrouping and rearranging has been stimulated and considered a premise for building new countryside in several provinces in the Red River Delta. Recently, land consolidation has become increasingly concerning, which is reflected in the requirement for large fields and cooperation in agricultural commodity production.

\subsubsection{Current Situation of Land Consolidation in Vietnam and the Red River Delta}

The implementation of the above national policies in the whole country achieved specific results. The average number of land parcels per farm household decreased from 7.8 in 1998 to 3.8 parcels in 2001 [14] (p. 197) as a result of the "Regrouping and Rearranging Land Parcels" Program. It subsequently decreased slightly from 2.8 to 2.5 parcels during the period of 2011-2016 [45]. The encouragement of farm economics and land consolidation also provides incentives to the LUR market. The transfer of agricultural LURs during this time has been more common in the south and in the Mekong River Delta.

The program of creating large fields by the Ministry of Agriculture and Rural Development was implemented nationwide from 2009-2010, originated from Decision 80/2002/QD-TTg, and was approved by many localities. Until 2016, Vietnam had 2262 large fields, which were concentrated mainly in the Red River Delta (31\%), the North Central and South Central Coast (30\%), and the Mekong River Delta (25\%) [45] (pp. 29-30). The rapid growth of agricultural farms in the whole country has also been observed. At the same time, it was recorded that, in the whole country, there were 33,488 farms, increasing by $67.2 \%$ relative to 2011 [45] (p. 28).

In spite of various efforts of the government, land fragmentation in Vietnam has still been a hindrance to large-scale agricultural production in Vietnam [11]. Land fragmentation in Vietnam is mainly triggered by historical equitable land allocation process, "inadequate regulatory framework and high transactions costs" [14] (p. 198). Recently, the shortage of agricultural land per capita has become an additional cause of land fragmentation. From 1990 until now, the rapid increase in industrialization and urbanization has gradually imposed high pressure on agricultural land because of the need to convert a large area of agricultural land into nonagricultural land. Agricultural land in Vietnam is now quite scarce, with only 0.12 ha per capita, equaling $1 / 6$ the average global value [9] (p. 20). The average agricultural land area per farm household rapidly decreased from $4121 \mathrm{~m}^{2}$ to $3334 \mathrm{~m}^{2}$ in the period from 1993 to 2014 [46]. The number of households that have less than 0.5 ha in area of cultivated land still accounts for $69 \%$. The other households with areas from 0.5 to 2 ha and more than 2 ha account for $25 \%$ and $6 \%$, respectively [45] (pp. 9-10). Land fragmentation in the north (Red River Delta) is even more severe than that in the south (Mekong River Delta) [15].

According to the 2019 Population and Housing Census, the Red River Delta has the largest population in the country, with 22.5 million people, reaching nearly $23.4 \%$ of the total population [47] (p. 74). Meanwhile, the agricultural land area in this delta covers 791.7 thousand ha, accounting for only $6.9 \%$ of the total agricultural land area of the country in 2017 [48]. The Red River Delta is the second-largest delta in the country, but its land fragmentation is worse than that of the Mekong River Delta, which is the largest delta, due to the differences in the historical contexts of land allocation [30], the scale of land ownership (during the colonial period) [49], the mechanization process, and the opportunity of farmers to transfer to nonagricultural sectors [50]. In contrast, in the Mekong River Delta, the proportion of households possessing more than 2 ha of agricultural land area is above $10 \%$, while it accounted for only $0.1 \%$ in the Red River Delta in 2011 [51] (pp. 11-12). 
Despite forming a higher number of large fields, the Red River Delta possesses only 67.6 thousand hectares of large fields, with an area of only 96 ha/large field, and 375 households cultivating each large field [45] (pp. 30-31). Meanwhile, the Mekong River Delta possesses 427.8 thousand hectares of large fields, with only 50 households cultivating each [45]. It is also proven that LURs tend to be sold rather than rented in the south, while the private and communal rental market is more active in the north [15]. In the Red River Delta, land consolidation is conducted under the primary forms of renting LURs, land accumulation, and land parcel exchanges. However, other forms, such as capital contribution with LURs, creating large fields, and self-land exchanges, occur to lesser degrees and contain several inadequacies [52].

\section{Case Studies and Methodologies}

\subsection{Case Studies}

In the Red River Delta, Hung Yen is one of the pilot provinces undertaking the whole process of land consolidation. The agricultural land area in this province was 60,369 ha in 2017, accounting for $64.9 \%$ of the total area [53]. The land consolidation process in Hung Yen Province was conducted in two periods: from 2001 to 2003 and from 2013 to 2015. After this process, the average number of parcels per household decreased from 6-7 to 1.56, creating advantageous conditions for farm households to increase agricultural commodity production. For the research, we selected Nhat Quang and Minh Hoang communes in Phu Cu District (Figure 1), one of the representative communes in Hung Yen Province; these communes successfully conducted the early steps of land consolidation. Consolidated land in Phu Cu District, obtained through land acquired by auction (from 5\% communal land (In Vietnam, according to the Land Law, $5 \%$ communal land is a part of the agricultural land in a commune that is reserved for future construction of public works of the commune (if existing). An area of this kind of land could not exceed 5\% of the total agricultural land area of a commune. The People Committee could lease 5\% communal land for agricultural production, but for not exceeding 5 years.) of the People's Committee) or renting agricultural LURs from local households, covers a total area of 88.75 ha. Almost all agricultural farms in this district cover an average area of less than 3 ha [54].

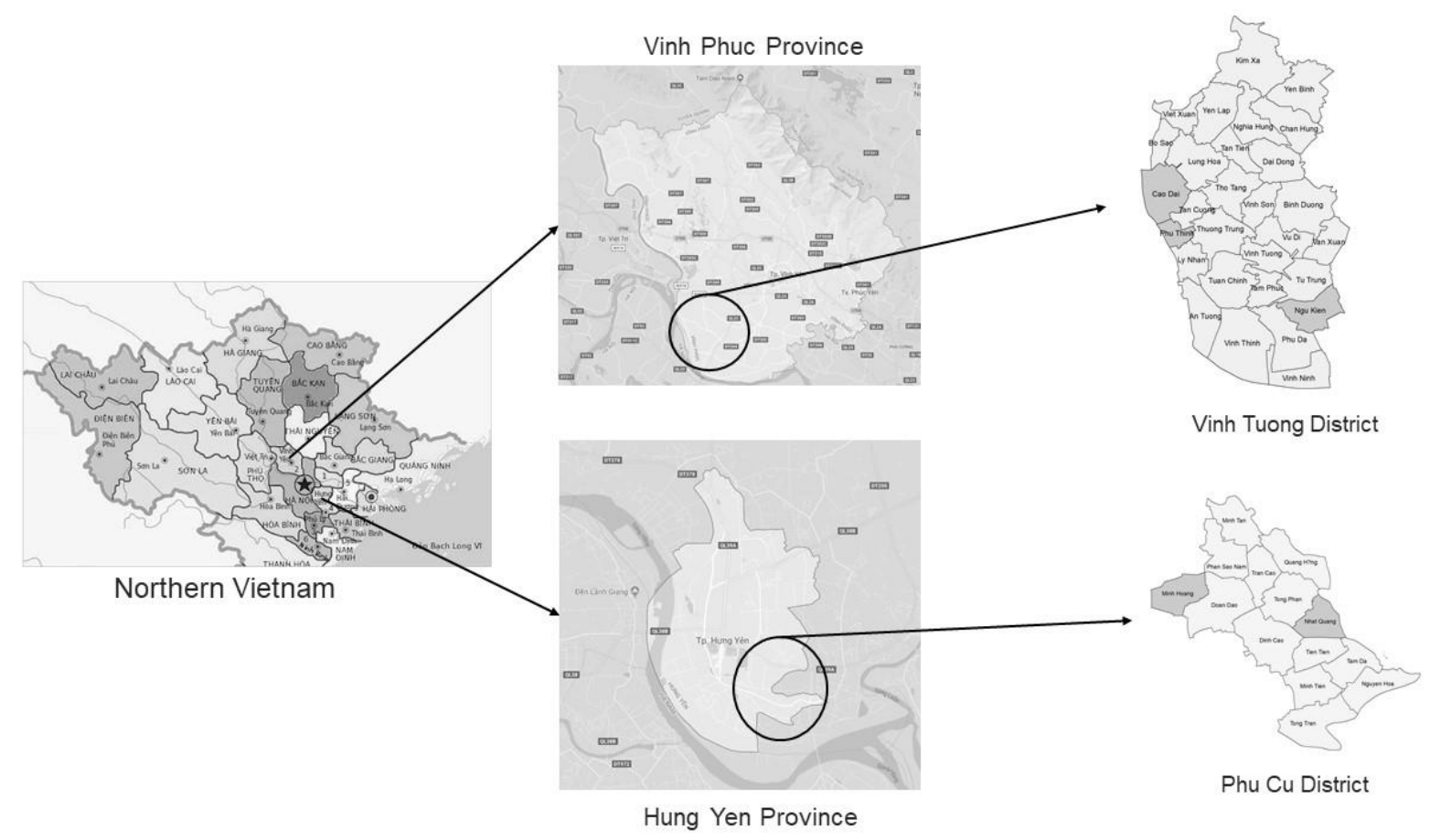

Figure 1. Map of case studies. 
To make a comparison of the efficiency of land consolidation with case studies in Hung Yen Province, we selected Vinh Phuc, another province in the Red River Delta that is representative of land fragmentation. The agricultural land area of the province was 92,823 ha in 2017 , accounting for $74.8 \%$ of the total land area [55]. Immediately after 1993, the average number of parcels per household in this province ranged from 7 to 10 parcels [55], which was much higher than the average number in the Red River Delta (5.5 parcels/household) [56]. Some households cultivated in even more than 20 separate parcels [56]. The largest parcel was approximately $720 \mathrm{~m}^{2}$, and the smallest parcel was just over $10 \mathrm{~m}^{2}$ [57]. Since 1996, the province has conducted three stages of land consolidation, but the rate of progress has been slow. Some pig and poultry ranches and fruit farms have been developed in Vinh Phuc Province, and they were mainly derived by contracting $5 \%$ of the communal land from the People's Committee and renting LURs from other households; most are operated at a small household scale (approximately 1-2 ha of farm area/household) [55]. In 2016, the province conducted one more stage of land consolidation in two pilot communes: Cao Dai and Ngu Kien communes, Vinh Tuong District (Figure 1). This period of the program gained some remarkable results. Since 2017, the District People's Committee has selected five additional communes for the land consolidation program, and Phu Thinh commune in Vinh Tuong District (Figure 1) is one of them. In results, the differences of land parcels' area and spatial structure, kind of land use, benefits from agricultural production, ... between case studies in Phu Cu District and case studies in Vinh Tuong District will be clarified.

\subsection{Land Consolidation Process in the Research Areas}

There are five forms of land consolidation in Vietnam: LUR leasing (including land acquired by auction from $5 \%$ communal land), capital contribution with LURs, creating a large field, land exchanges (by self-negotiation), land regrouping, and land acquisition for high-tech agricultural projects. In our case studies, land regrouping (regrouping and rearranging land parcels) is a formal and initial procedure of land consolidation, widely affecting the central part of farm households. LUR renting is an additional form of land consolidation there, and it is popular among individual farm households.

In this paper, we concentrated on land consolidation in the case study from the latest official land regrouping until the present. The latest regrouping land was deployed by local governments at different times in each case study (during 2013-2015 in Nhat Quang and Minh Hoang communes, Phu Cu District; in 2016 in Cao Dai and Ngu Kien communes, 2017 in Phu Thinh commune, Vinh Tuong District).

Land consolidation in the case studies was generally conducted in 8 steps (Figure 2). While local governments, from the province level to the commune level, conduct the first step, local governments from the commune level to the village level, including a steering committee elected by the people's committee of a commune, are primarily responsible for creating a detailed plan for land consolidation and then implementing that plan in each subsequent step.

To date, Nhat Quang and Minh Hoang communes in Hung Yen Province have both moved to the 8th step. Meanwhile, Ngu Kien, Cao Dai, and Phu Thinh communes in Vinh Phuc Province are only at the 6th step. After step 7, enterprises and individual households can rent LURs from other farm households through a self-negotiation process or formal administrative procedures. 


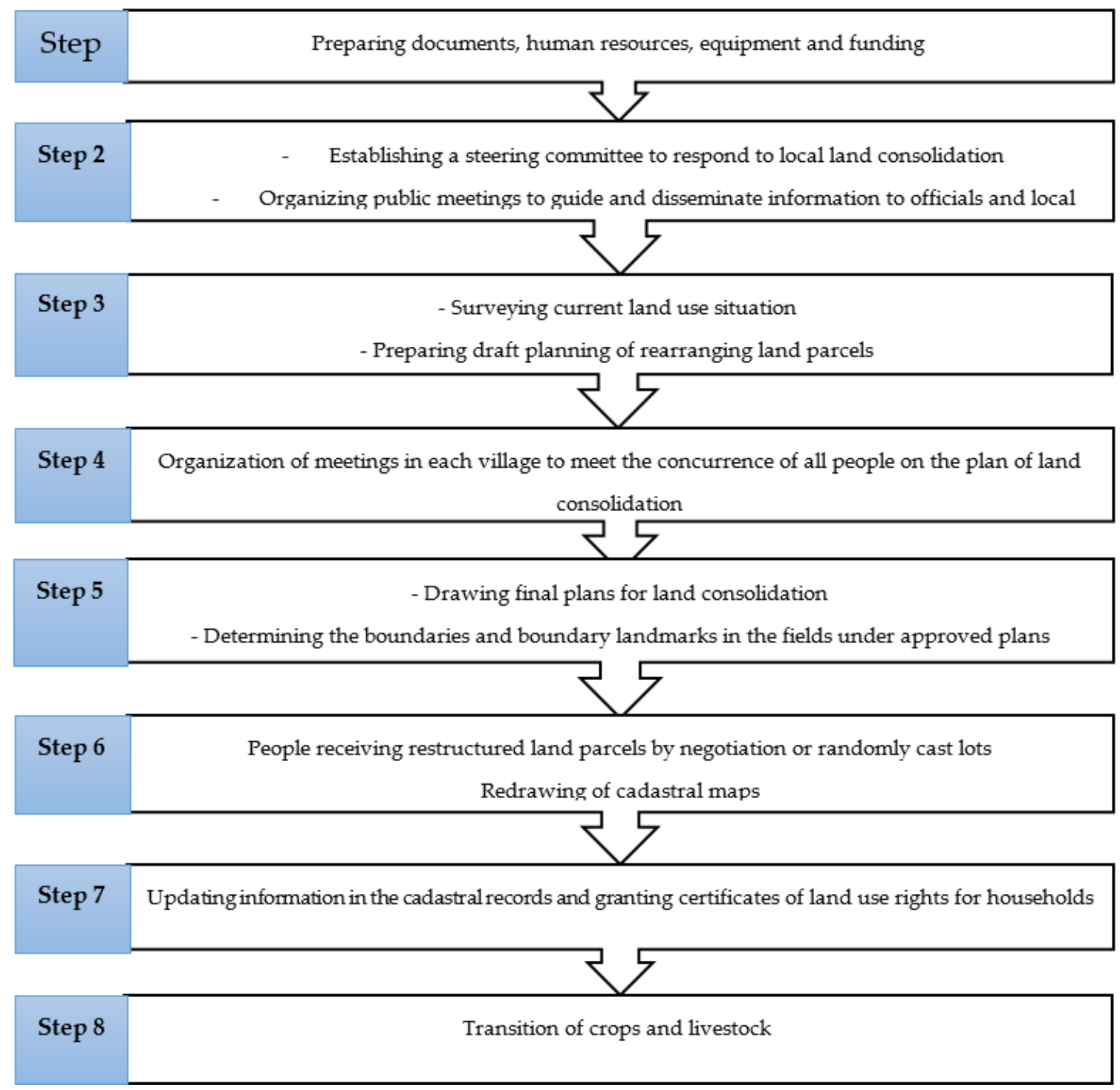

Figure 2. Process of regrouping land and crops and livestock conversion in land consolidation (drawn by the authors).

\subsection{Research Methodology}

To conduct the research, the authors mainly used the method of primary data collection (by household surveys and interviews with communal/village officials).

Household survey: The sociological survey was divided into two stages. The first stage was conducted in Nhat Quang and Minh Hoang communes, Phu Cu District, Hung Yen Province for the period of 22-27 November 2018. The second stage was implemented in Ngu Kien, Cao Dai, and Phu Thinh communes, Vinh Tuong District, Vinh Phuc Province, for the period of 6-11 December 2018. A self-designed structured questionnaire was used for this survey to obtain information on the local farmers' concurrence about the effectiveness of the socioeconomic and environmental results of land consolidation. A list of interviewed households was selected under the combination of simple randomization and stratification based on the official list of local households that have implemented land consolidation in each study area. A total of 172 questionnaires were finally chosen for descriptive statistics after checking and removing questionnaires that were illogical and lacked the necessary information (see more detail in Tables 2 and 3). 
Table 2. The numbers of structured questionnaires and in-depth interviews in the study areas.

\begin{tabular}{|c|c|c|c|c|}
\hline Province & District & Commune & $\begin{array}{c}\text { Number of Structured } \\
\text { Questionnaires }\end{array}$ & $\begin{array}{l}\text { In-Depth } \\
\text { Interviews }\end{array}$ \\
\hline \multirow{2}{*}{ Hung Yen } & \multirow{2}{*}{ Phu Cu } & Nhat Quang & 52 & 4 \\
\hline & & Minh Hoang & 33 & 3 \\
\hline \multirow{3}{*}{ Vinh Phuc } & \multirow{3}{*}{ Vinh Tuong } & Ngu Kien & 33 & 5 \\
\hline & & Cao Dai & 32 & 6 \\
\hline & & Phu Thinh & 22 & 4 \\
\hline
\end{tabular}

Table 3. Percentage of responses for each question in structured questionnaire.

\begin{tabular}{|c|c|c|c|}
\hline No & Question & $\begin{array}{l}\text { Phu Cu } \\
\text { District }\end{array}$ & $\begin{array}{l}\text { Vinh Tuong } \\
\text { District }\end{array}$ \\
\hline \multirow{18}{*}{1.0} & Information about agricultural land of an interviewed household & & \\
\hline & Total agricultural area before the latest land consolidation & 100 & 100 \\
\hline & Total agricultural area allocated by the state before the latest land consolidation & 100 & 100 \\
\hline & Total agricultural area rented from $5 \%$ communal land before the latest land consolidation & 100 & 100 \\
\hline & Total agricultural area rented from other households before the latest land consolidation & 100 & 100 \\
\hline & Total number of parcels before the latest land consolidation & 97.6 & 100 \\
\hline & An area of the largest parcel before the latest land consolidation & 94.1 & 100 \\
\hline & An area of the smallest parcel before the latest land consolidation & 92.4 & 100 \\
\hline & Type of land use before the latest land consolidation & 100 & 100 \\
\hline & Total agricultural area after the latest land consolidation & 100 & 100 \\
\hline & Total agricultural area allocated by the state after the latest land consolidation & 100 & 100 \\
\hline & Total agricultural area rented from $5 \%$ communal land after the latest land consolidation & 100 & 100 \\
\hline & Total area of agriculture rented from other households after the latest land consolidation & 100 & 100 \\
\hline & Total number of parcels after the latest land consolidation & 100 & 100 \\
\hline & An area of the largest parcel after the latest land consolidation & 100 & 99 \\
\hline & An area of the smallest parcel after the latest land consolidation & 100 & 99 \\
\hline & Type of land use after the latest land consolidation & 100 & 100 \\
\hline & Forms of land consolidation & 98.8 & 80.5 \\
\hline \multirow{5}{*}{2.0} & The Degree of Agreement with Each Statement about Economic Benefit from Agriculture & & \\
\hline & $\begin{array}{l}\text { Do you agree that there is an increase in your benefit from agricultural production after the } \\
\text { latest land consolidation? }\end{array}$ & 98.8 & 100 \\
\hline & $\begin{array}{l}\text { In your opinion, how many times do you benefit from agriculture increase after the latest } \\
\text { land consolidation (if existing)? }\end{array}$ & 82.4 & 88.5 \\
\hline & $\begin{array}{l}\text { If the total revenue of your households covers } 10 \text { points, how much is your benefit from } \\
\text { agriculture? }\end{array}$ & 98.8 & 100 \\
\hline & Do you agree that your benefit from agriculture is enough to cover your living expenses? & 98.8 & 100 \\
\hline \multirow{7}{*}{3.0} & Information about Hired Labors for Agricultural Production of an Interviewed Household & & \\
\hline & Do you hire regular workers for agricultural production before the latest land consolidation? & 100 & 100 \\
\hline & If yes, how much are the regular workers? & 100 & 100 \\
\hline & Did you hire temporary workers for agricultural production before the latest land consolidation? & 100 & 100 \\
\hline & Did you hire regular workers for agricultural production after the latest land consolidation? & 100 & 98.8 \\
\hline & If yes, how much are the regular workers? & 100 & 98.8 \\
\hline & Did you hire temporary workers for agricultural production after the latest land consolidation? & 100 & 79.3 \\
\hline
\end{tabular}


Table 3. Cont.

\begin{tabular}{|c|c|c|c|}
\hline No & Question & $\begin{array}{l}\text { Phu Cu } \\
\text { District }\end{array}$ & $\begin{array}{l}\text { Vinh Tuong } \\
\text { District }\end{array}$ \\
\hline \multirow{9}{*}{4.0} & The Usage of Machinery for Agricultural Production & & \\
\hline & $\begin{array}{l}\text { Did your household use plows and harrows on any of your parcels before the latest } \\
\text { land consolidation? }\end{array}$ & 98.8 & 100 \\
\hline & Did your household use reapers on any of your parcels before the latest land consolidation? & 98.8 & 100 \\
\hline & $\begin{array}{l}\text { Did your household use combine harvesters on any of your parcels before the latest } \\
\text { land consolidation? }\end{array}$ & 98.8 & 100 \\
\hline & $\begin{array}{l}\text { Did your household use cultivator machines on any of your parcels before the latest } \\
\text { land consolidation? }\end{array}$ & 98.8 & 100 \\
\hline & $\begin{array}{l}\text { Does your household use plows and harrows on any of your parcels after the latest } \\
\text { land consolidation? }\end{array}$ & 98.8 & 100 \\
\hline & Does your household use reapers on any of your parcels after the latest land consolidation? & 98.8 & 100 \\
\hline & $\begin{array}{l}\text { Does your household use combine harvesters on any of your parcels after the latest } \\
\text { land consolidation? }\end{array}$ & 98.8 & 100 \\
\hline & $\begin{array}{l}\text { Does your household use cultivator machines on any of your parcels after the latest } \\
\text { land consolidation? }\end{array}$ & 98.8 & 100 \\
\hline \multirow{10}{*}{5.0} & $\begin{array}{l}\text { The Degree of Agreement with Each Statement about the Effectiveness of } \\
\text { Land Consolidation }\end{array}$ & & \\
\hline & Do you agree that land consolidation helps you reduce the traveling time to each land parcel? & 98.8 & 100 \\
\hline & $\begin{array}{l}\text { Do you agree that land consolidation helps to improve the ability to apply machinery } \\
\text { on agriculture? }\end{array}$ & 98.8 & 100 \\
\hline & Do you agree that land consolidation helps to improve the ability to apply high technology? & 97.6 & 97.6 \\
\hline & $\begin{array}{l}\text { Do you agree that land consolidation helps to increase the opportunity to stably work for more } \\
\text { laborers in agriculture? }\end{array}$ & 98.8 & 98.8 \\
\hline & Do you agree that land consolidation helps to reduce the amount of pesticides on crops? & 98.8 & 100 \\
\hline & Do you agree that land consolidation helps to reduce the amount of inorganic fertilizer on crops? & 98.8 & 100 \\
\hline & Do you agree that land consolidation helps to improve the village landscape scenery? & 98.8 & 100 \\
\hline & Do you agree that the soil environment can be improved due to land consolidation? & 98.8 & 100 \\
\hline & Do you agree with the local policies on land consolidation? & 98.8 & 100 \\
\hline
\end{tabular}

+ In-depth interviews with communal and village officials: In the study areas, we conducted in-depth interviews with a total of 22 local officials (see more detail in Table 2) by using semi-structured questionnaires to collect more detailed information on local policies related to land consolidation and on the local process of regrouping land and the conversion of crops and livestock. General economic benefits of popular crops in Phu Cu and Vinh Tuong were also collected from these interviews.

\section{Research Results}

\subsection{Expanding the Land Area of Farm Households}

In Phu Cu District and Vinh Tuong District, the process of land consolidation is reflected by the distinct transition of the current land use structure of local farm households, typically in the percentages of allocated land (Allocated land is the land periodically issued by the State to farm households having land use demand by the State.) and rented land (Rented land is the land leased by the State or other households to farm households having land use demand, under contracts on renting land use rights, with limited renting terms. However, some land rented from the privates may not have official contracts.) (Table 4).

According to the survey results, both the total agricultural land area and the average agricultural land area of each interviewed household has increased as a result of the stimulated process of renting $5 \%$ communal land from the People's Committee or agricultural land from other local households. 
Table 4. Transformation of the structure of agricultural land use area.of the interviewed households during land consolidation.

\begin{tabular}{ccccc}
\hline & \multicolumn{2}{c}{ Case Studies in Phu Cu District } & \multicolumn{2}{c}{ Case Studies in Vinh Tuong District } \\
\cline { 2 - 5 } & $\begin{array}{c}\text { Before the Latest } \\
\text { Land Regrouping }\end{array}$ & Present & $\begin{array}{c}\text { Before the Latest } \\
\text { Land Regrouping }\end{array}$ & Present \\
\hline $\begin{array}{c}\text { The total agricultural land area of the interviewed } \\
\text { households }\left(\mathrm{m}^{2}\right)\end{array}$ & 269,397 & 490,312 & 170,432 & 312,094 \\
\hline $\begin{array}{c}\text { Average agricultural land area per a household }\left(\mathrm{m}^{2}\right) \\
\text { Average annual cropland area per household }\left(\mathrm{m}^{2}\right)\end{array}$ & 3367 & 5768 & 1982 & 3587 \\
\hline $\begin{array}{c}\text { Average perennial crop and farmland area per } \\
\text { household }\left(\mathrm{m}^{2}\right)\end{array}$ & 3360 & 3765 & 1960 & 2348 \\
\hline $\begin{array}{c}\text { Proportion of allocated land area }(\%) \\
\text { Proportion of rented communal land area }(\%)\end{array}$ & 96.4 & 7388 & - & 11,161 \\
\hline $\begin{array}{c}\text { Proportion of rented land area from other local } \\
\text { households }(\%)\end{array}$ & 0.6 & 28.3 & 2.0 & 56.4 \\
\hline
\end{tabular}

Source: household survey, 2018.

The average land area of each interviewed household was also different depending on the land use types. In both cases, the average annual cropland area moderately increased, and the average land area for perennial crops and farms rose more impressively (see Table 4). In contrast with annual cropland, the average perennial crop and farmland area in Vinh Tuong covered $11,161 \mathrm{~m}^{2}$ per household, which was much higher than that in $\mathrm{Phu} \mathrm{Cu}\left(7388 \mathrm{~m}^{2}\right)$.

The increasing number of households attaining more than 1 ha of agricultural land area after the latest land regrouping was also considerable. Previously, only one household obtained 1 ha of agricultural land area in Phu Cu District, while no household obtained this amount in Vinh Tuong District. However, immediately after land consolidation, there were 11 households in Phu $\mathrm{Cu}$ (with an average land area of 14,125 $\mathrm{m}^{2}$ per household) and 8 households in Vinh Tuong cultivating a total area greater than 1 ha per household (with an average land area of $15,410 \mathrm{~m}^{2}$ per household). There is an example of a farm that successfully self-accumulated land to form a mixed farm in Vinh Tuong, with an area of $28,800 \mathrm{~m}^{2}$ (from the original $1440 \mathrm{~m}^{2}$ of annual cropland), in addition to $10,800 \mathrm{~m}^{2}$ of land area located in another province.

\subsection{Changes in the Spatial Structure of Land Parcels}

The effect of land consolidation is also notably represented by the changes in area, fragmentation level of each land parcel, total land area, and number of parcels owned by each farm household in the research areas (Table 5).

The changes in the average number of land parcels of each household after land consolidation were clearly recognized. In Phu Cu, as a result of early land consolidation, each household retained only 3.7 agricultural land parcels, which was much lower than that in the Red River Delta. Since the latest land regrouping, this number has decreased to only 1.3 parcels per household. The most significant number of land parcels of a household was four parcels. As was typical, there was a household that successfully consolidated nine fragmented land parcels into only one large parcel. In Vinh Tuong, either mountainous and hilly terrain or late and ineffective application of land consolidation caused more serious land fragmentation than that of $\mathrm{Phu} \mathrm{Cu}$. Before the latest land regrouping, the average number of land parcels in Vinh Tuong was 6.2 parcels per farm household. The largest number of parcels of a household was 12, while the lowest number was two parcels. Currently, the average number of land parcels per household has decreased to 2.4 parcels. The largest number of parcels of a household is six parcels, while the lowest number was only one parcel.

Accordingly, the average area of each parcel in Phu Cu was much larger than that in Vinh Tuong (see Table 6). This pattern is also distinctively shown in Figures 3 and 4. 
Table 5. Changes in area and number of agricultural land parcels. of interviewed households during land consolidation.

\begin{tabular}{|c|c|c|c|c|}
\hline & \multicolumn{2}{|c|}{ Case Studies in Phu Cu District } & \multicolumn{2}{|c|}{ Case Studies in Vinh Tuong District } \\
\hline & $\begin{array}{l}\text { Before the Latest } \\
\text { Land Regrouping }\end{array}$ & Present & $\begin{array}{l}\text { Before the Latest } \\
\text { Land Regrouping }\end{array}$ & Present \\
\hline $\begin{array}{c}\text { The average area of the largest } \\
\text { parcel of a household }\left(\mathrm{m}^{2}\right)\end{array}$ & 1521 & 5216 & 500 & 2449 \\
\hline $\begin{array}{l}\text { Area of the largest parcel in the } \\
\text { research areas }\left(\mathrm{m}^{2}\right)\end{array}$ & 4680 & 26,496 & 1800 & 18,000 \\
\hline $\begin{array}{l}\text { The average area of the smallest } \\
\text { parcel of a household }\left(\mathrm{m}^{2}\right)\end{array}$ & 505 & 1747 & 155 & 821 \\
\hline $\begin{array}{l}\text { Area of the smallest parcel in the } \\
\text { research areas }\left(\mathrm{m}^{2}\right)\end{array}$ & 360 & 972 & 144 & 384 \\
\hline $\begin{array}{l}\text { The average number of land } \\
\text { parcels of a household }\end{array}$ & 3.7 & 1.3 & 6.2 & 2.4 \\
\hline $\begin{array}{l}\text { The largest number of land } \\
\text { parcels of a household }\end{array}$ & 11 & 4 & 12 & 6 \\
\hline $\begin{array}{l}\text { The smallest number of land } \\
\text { parcels of a household }\end{array}$ & 1 & 1 & 2 & 1 \\
\hline
\end{tabular}

Source: household survey, 2018.

Table 6. The transformation of agricultural land parcels after land regrouping in the case studies.

\begin{tabular}{cccccc}
\hline \multirow{2}{*}{ District } & Commune & $\begin{array}{c}\text { Total Land Area } \\
\text { for Consolidation } \\
\text { (ha) }\end{array}$ & $\begin{array}{c}\text { The Average Area Per } \\
\text { Parcel Before the Latest } \\
\text { Land Regrouping }\end{array}$ & $\begin{array}{c}\text { The Average Area Per } \\
\text { Parcel After the Latest } \\
\text { Land Regrouping }\end{array}$ & $\begin{array}{c}\text { Number of Participating } \\
\text { Households in the Latest } \\
\text { Land Regrouping }\end{array}$ \\
\hline \multirow{2}{*}{ Phu Cu } & Nhat Quang & 274.83 & 921.1 & 1794.83 & 1389 \\
\cline { 2 - 6 } & Minh Hoang & 322.49 & 1029.6 & 1942.7 & 1249 \\
\hline \multirow{3}{*}{ Vinh Tuong } & Cao Dai & 157.1 & 264.7 & 864.6 & 1034 \\
\cline { 2 - 6 } & Ngu Kien & 229.6 & 269.2 & 988.0 & 1405 \\
\cline { 2 - 6 } & Phu Thinh & 19.84 & 234.1 & 1210.3 & 158 \\
\hline \multicolumn{5}{c}{ Source: [57-61]. }
\end{tabular}

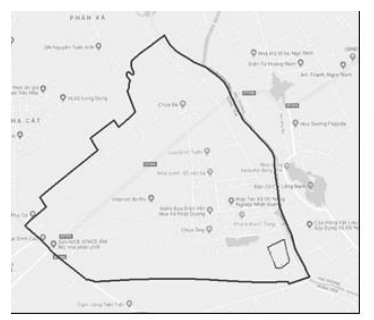

Before land consolidation

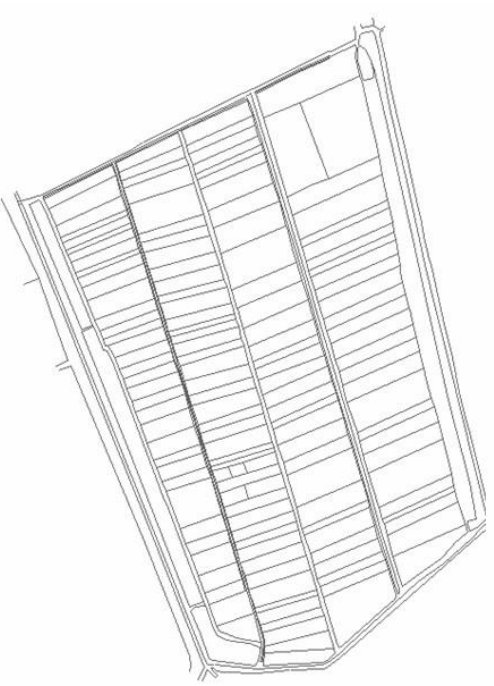

After land consolidation

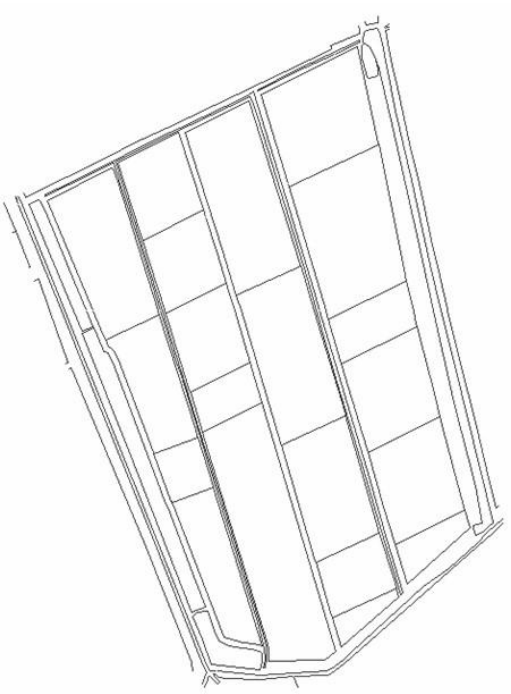

Figure 3. An example map of the pattern of agricultural land parcels before and after the latest land regrouping in Nhat Quang commune, Phu Cu District. 

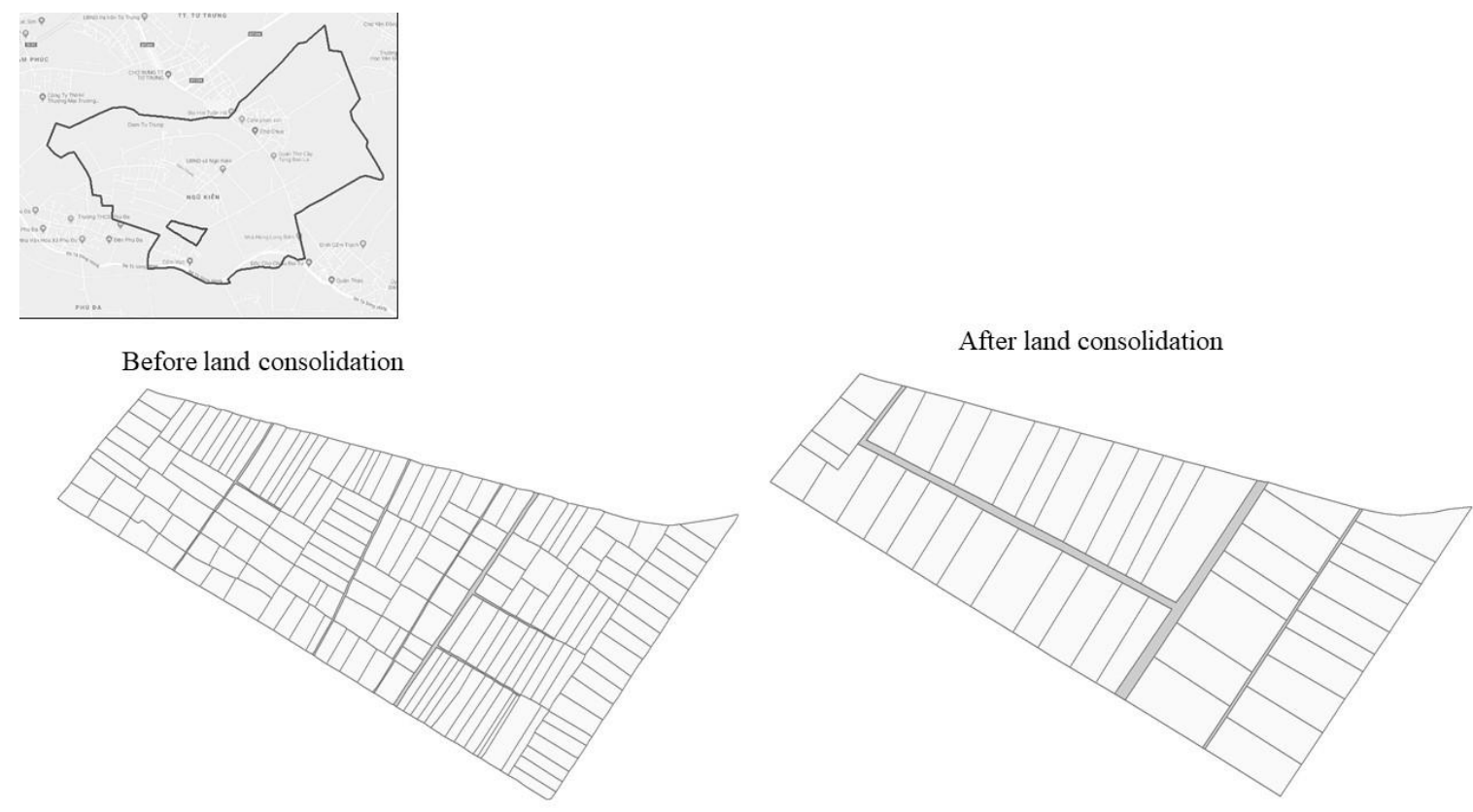

Figure 4. An example map of the pattern of agricultural land parcels before and after the latest land regrouping in Ngu Kien commune, Vinh Tuong District.

4.3. Changes in Crop Structure, Increase in Household Income, and Provision of More Opportunities for Larger-Scale Agricultural Production

Corresponding to the transformation in the spatial structure of land parcels, the structure of crops in consolidated parcels has also been changed. In both Phu $\mathrm{Cu}$ and Vinh Tuong Districts, before land consolidation, annual cropland was the dominant cover type, and typically, two-crop paddy and subsidiary crops were grown, such as vegetables, maize, peanuts, and soybeans. There were several parcels that could grow only a one-crop paddy because of its low topography. However, after land consolidation, a large area of annual cropland, including low land, was converted into mixed farms or perennial crop (fruit) land (Table 7), typically in the research areas in Phu Cu rather than those in Vinh Tuong.

Table 7. The proportion of households by agricultural land use structure.

\begin{tabular}{|c|c|c|c|c|c|c|}
\hline & \multicolumn{2}{|c|}{$\begin{array}{c}\text { The Proportion of Households } \\
\text { Mainly Growing Paddy and } \\
\text { Annual Crops }\end{array}$} & \multicolumn{2}{|c|}{$\begin{array}{l}\text { The Proportion of Households Mainly } \\
\text { Planting Fruit (Perennial Cropland) }\end{array}$} & \multicolumn{2}{|c|}{$\begin{array}{l}\text { The Proportion of Households } \\
\text { Mainly Doing Mixed Farms }\end{array}$} \\
\hline & $\begin{array}{l}\text { Before the Latest } \\
\text { Land Regrouping }\end{array}$ & Present & $\begin{array}{l}\text { Before the Latest Land } \\
\text { Regrouping }\end{array}$ & Present & $\begin{array}{l}\text { Before the Latest } \\
\text { Land Regrouping }\end{array}$ & Present \\
\hline Phu Cu & 100 & 42.4 & 0.0 & 12.9 & 0.0 & 44.7 \\
\hline Vinh Tuong & 100 & 87.4 & 0.0 & 3.4 & 0.0 & 9.2 \\
\hline
\end{tabular}

Source: household survey, 2018.

In $\mathrm{Phu} \mathrm{Cu}$, while the former stages of land consolidation mostly resulted in the changes in spatial structure, the latest stage of land consolidation has started alternating the crop structure. Before this process, $100 \%$ of interviewed households mainly grew paddy and other crops on their agricultural land, but after that, the number decreased to only $41.7 \%$. Meanwhile, $14.3 \%$ of households have converted their annual cropland to perennial cropland, and up to $44 \%$ of other households have invested more in capital and machinery to make mixed farms (growing fruit trees, raising pigs or cattle, and doing aquaculture) on their consolidated land.

In Vinh Tuong, land consolidation has not yet received good results, partly because the local policies and administrative mechanisms have not yet provided incentives for the conversion of the 
crop structure on a large scale and partly because the local people lacked capital, experience, and cooperation to engage in farm economics. After the latest land consolidation, most of the local farmers still cultivated paddies and other annual crops on their agricultural land. Only approximately $1.2 \%$ of interviewed households changed to planting fruit trees, and $11.6 \%$ of households individually and autonomously tried to create mixed farms instead of small-scale annual crops.

In terms of economic efficiency, it is well known that planting fruit trees or having mixed farms obtains a higher gross profit than does growing annual crops (see more details in Table 8). Our survey data indicated that the average gross profit of a mixed farm in Phu $\mathrm{Cu}$ was as high as 350 million VND/year, while that in Vinh Tuong was less than 200 million VND/year. Households in Phu Cu usually obtained higher gross profits from fruit trees than did households in Vinh Tuong, as they have spent more time researching and finding proper fruits for their local soil, and because the local government has carried out the land consolidation process to the final step, reaching the end result much earlier. Furthermore, engaging in farm economics requires the farmers to have good knowledge about planting fruit trees, breeding cattle or pigs, and operating aquaculture, and they must have a large amount of investment capital and more labor efforts.

Table 8. Comparison of profits from the main annual and perennial crops in the research areas.

\begin{tabular}{|c|c|c|c|c|c|}
\hline \multirow[t]{2}{*}{ Crops } & \multicolumn{2}{|c|}{$\begin{array}{l}\text { Average Gross Profit } \\
\text { (1000 VND/ha/Year) }\end{array}$} & \multicolumn{2}{|c|}{$\begin{array}{l}\text { Initial Investment } \\
(1000 \mathrm{VND} / \mathrm{ha})\end{array}$} & \multirow[t]{2}{*}{$\begin{array}{l}\text { Years Spent to } \\
\text { Harvest (Year) }\end{array}$} \\
\hline & Phu Cu & Vinh Tuong & Phu Cu & Vinh Tuong & \\
\hline Two-crop paddy & 13,811 & 11,800 & - & - & - \\
\hline $\begin{array}{l}\text { Two-crop paddy + wax gourd } \\
\text { (winter season) }\end{array}$ & 53,612 & 49,675 & - & - & - \\
\hline $\begin{array}{l}\text { Two-crop paddy + maize } \\
\text { (winter season) }\end{array}$ & 29,185 & 27,730 & - & - & - \\
\hline Banana trees & 85,146 & 72,480 & - & - & 1 \\
\hline Orange trees & 258,000 & - & 180,603 & - & 3 \\
\hline Grapefruit trees & 246,440 & 164,440 & 80,678 & 55,640 & 3 \\
\hline Longan fruit trees & 173,780 & - & 45,676 & - & 3 \\
\hline Lychee tree & 128,950 & - & 65,889 & - & 3 \\
\hline
\end{tabular}

Source: In-depth interview with local officials, 2018.

Many of the interviewed households also admitted that growing paddy in larger and contiguous land parcels significantly increased their income, approximately 30-40\% higher than before; the increase was obtained by the need for fewer working laborers, less fertilizers and pesticides and higher crop productivity. For some, income increased by more than two times.

In spite of this, there are still some worse cases, especially in Vinh Tuong. Some households attained consolidated land with better soil quality but less land area, while others received consolidated land in a larger area but with lower-quality soil that was not suitable for growing paddies. To maintain crop yields, $15.5 \%$ of households in Phu Cu District and 19.5\% of households in Vinh Tuong District said that they had to use more pesticides for their consolidated land. Meanwhile, up to $17.9 \%$ of households in Phu Cu and 29.9\% of households in Vinh Tuong had to add more inorganic fertilizer to the soil.

Economic profits from agricultural land also directly impact the structure of household income. In $\mathrm{Phu} \mathrm{Cu}, 47.6 \%$ of the interviewed households, especially those engaging in farm economics, affirmed that they could live mainly based on agriculture. Meanwhile, in Vinh Tuong, 74.7\% of the interviewed households expressed that the low profits from annual crops were not enough to cover the living expenses of the interviewed households, and most of them needed to seek out additional nonagricultural income. 


\subsection{Accelerating Mechanization in Agricultural Production}

In the past, agricultural land was fragmented, and most of the land parcels were located inside the fields and far from large roads, particularly in Vinh Tuong. Any type of large machine could not access the inside of the land parcels without passing through other land parcels. It is clearly proven that land consolidation creates a larger field and broader roads, and every land parcel becomes adjacent to a large road; thus, the use of modern machines in rice transplanting and harvesting is much more convenient. This change marks the intensification of farm households being able to use plows and harrows, reapers, harvesters, and cultivator machines for cultivation (see Table 9).

Table 9. Changes in the proportion of households applying machinery in rice cultivation during land consolidation.

\begin{tabular}{cccccc}
\hline \multirow{2}{*}{$\mathrm{Phu} \mathrm{Cu}$} & $\begin{array}{c}\text { Used Plows } \\
\text { and Harrows }\end{array}$ & $\begin{array}{c}\text { Used } \\
\text { Reapers }\end{array}$ & $\begin{array}{c}\text { Used } \\
\text { Harvesters }\end{array}$ & $\begin{array}{c}\text { Used Cultivator } \\
\text { Machines }\end{array}$ \\
\hline & $\begin{array}{c}\text { Before the latest } \\
\text { land consolidation }\end{array}$ & 50.6 & 17.7 & 11.4 & 1.3 \\
\cline { 2 - 5 } Vinh Tuong & $\begin{array}{c}\text { After the latest } \\
\text { land consolidation }\end{array}$ & 91.4 & 88.6 & 51.4 & 11.4 \\
\cline { 2 - 5 } $\begin{array}{c}\text { Before the latest } \\
\text { land consolidation }\end{array}$ & 70.9 & 25.6 & 7.0 & 17.4 \\
\hline $\begin{array}{c}\text { After the latest } \\
\text { land consolidation }\end{array}$ & 96.1 & 89.5 & 56.6 & 50 \\
\hline
\end{tabular}

Source: household survey, 2018.

Although the effectiveness of land consolidation on mechanization in rice cultivation is clear, land consolidation is not the only factor leading to it. It needs to take into account other factors, such as the financial capital, the willingness of applying or investment in machinery, and the time spent for rice cultivation of a farm household.

\subsection{Create More Job Opportunities for Agricultural Laborers}

From another perspective, it can be positively acknowledged that opportunities in agricultural work for local agricultural laborers are rising. While seasonal laborers mainly took part in rice transplanting and harvesting before land consolidation, they have more job opportunities in perennial cropland or mixed farms (such as weeding and picking fruits) after land consolidation.

In addition, with annual cropland, there is no demand for such permanent hired workers in any interviewed households. However, with perennial crops and farmland, this demand has risen (see Table 10), though at a slow rate. More family laborers can be utilized to work on this kind of land use.

Table 10. Changes in labor demand in agriculture of the interviewed households during land consolidation.

\begin{tabular}{cccccc}
\hline & $\begin{array}{c}\text { The Proportion of Households } \\
\text { Hiring Permanent Agricultural } \\
\text { Labors (\%) }\end{array}$ & $\begin{array}{c}\text { The Average Number of Permanent } \\
\text { Hired Labors/Household }\end{array}$ & $\begin{array}{c}\text { The Proportion of Households } \\
\text { Hiring Seasonal Agricultural } \\
\text { Labors (\%) }\end{array}$ \\
\hline & $\begin{array}{c}\text { Before the Latest } \\
\text { Land Regrouping }\end{array}$ & Present & $\begin{array}{c}\text { Before the Latest Land } \\
\text { Regrouping }\end{array}$ & Present & $\begin{array}{c}\text { Before the Latest } \\
\text { Land Regrouping }\end{array}$ \\
\hline Phu Cu & 1.2 & 5.9 & - & 2.4 & 5.4 \\
\hline Vinh Tuong & 0 & 3.4 & - & 1.3 & 14.9 \\
\hline
\end{tabular}




\subsection{Farmers' Positive Perception of Land Consolidation}

Although the processes of land consolidation in the case studies in both Phu Cu and Vinh Tuong still need more time to encourage farmers to engage in agricultural commodity production, the positive attitude of the local farmers towards land consolidation is promising. In fact, $45.2 \%$ of the interviewed households in Phu Cu and 40.2\% of those in Vinh Tuong agree with the local policies and implementation plans of land consolidation. Meanwhile, 50\% of interviewed households in Phu $\mathrm{Cu}$ and $59.8 \%$ of those in Vinh Tuong strongly agree with this plan. Only a small percentage $(2.4 \%)$ of the interviewed households in Phu $\mathrm{Cu}$ disagree with the plans and complain about the lack of access to high land for sowing in paddy cultivation after land consolidation (see Table 11).

Table 11. Percentages of farmers agreeing with the effectiveness of land consolidation.

\begin{tabular}{cccc}
\hline & Degree of Agreement & Phu Cu District & Vinh Tuong District \\
\hline \multirow{2}{*}{$\begin{array}{c}\text { Local policies and } \\
\text { implementation plans }\end{array}$} & Strongly agree & 50 & 59.8 \\
\cline { 2 - 4 } & Agree & 45.2 & 40.2 \\
\hline \multirow{2}{*}{$\begin{array}{c}\text { Reduction in the field } \\
\text { traveling time }\end{array}$} & Disagree & 2.4 & 0.0 \\
\cline { 2 - 4 } & Strongly agree & 48.8 & 47.1 \\
\cline { 2 - 4 } $\begin{array}{c}\text { Increased probability of } \\
\text { applying mechanization in } \\
\text { cultivation }\end{array}$ & Agree & 48.8 & 49.4 \\
\cline { 2 - 4 } & Strongly agree & 1.2 & 1.1 \\
\hline \multirow{2}{*}{$\begin{array}{c}\text { Improvement in the scenery of } \\
\text { the village landscape }\end{array}$} & Agree & 35.7 & 43.7 \\
\cline { 2 - 4 } & Disagree & 59.5 & 1.1 \\
\cline { 2 - 4 } & Strongly agree & 3.6 & 60.9 \\
\hline \multirow{2}{*}{\begin{tabular}{c} 
Improved soil quality \\
\cline { 2 - 4 }
\end{tabular}} & Agree & 36.9 & 35.6 \\
\cline { 2 - 4 } & Disagree & 57.1 & 65.5 \\
\cline { 2 - 4 } & Strongly agree & 2.4 & 8.0 \\
\hline
\end{tabular}

Source: household survey, 2018.

The positive effects of land consolidation recognized by the majority of households can be listed as follows: a significant reduction in the field traveling time (97.6\% in Phu Cu and 96.5\% in Vinh Tuong), an increasing probability of applying mechanization in cultivation (95.2\% in Phu Cu and 97.7\% in Vinh Tuong), and an improvement in the scenery of the village landscape ( $94 \%$ of households in Phu Cu and $96.5 \%$ in Vinh Tuong). In addition, a large proportion of households recognize that land consolidation helps improve soil quality (94\% in Phu Cu and 73.5\% in Vinh Tuong) (by using less or more effective fertilizers and pesticides) (see Table 11).

These positive perceptions make the planning of land consolidation in the next phase in these localities more feasible and broader, getting the regions closer to agricultural commodity production.

\section{Discussion}

\subsection{Inadequacies of the Land Consolidation Process}

It is clearly recognized that land consolidation has practical benefits in relation to rural development. However, it is not an easy process to implement in the Red River Delta or in typical research areas. To conduct the process of land consolidation, changing the long-traditional self-sufficiency thought to the market-oriented commodity thought of farmers, and finding a practical plan for land consolidation while ensuring relative justice for several people, are both significant challenges for local governments. 
In our research areas, land consolidation steering committees should spend much time and effort in having several meetings (68 meetings in Nhat Quang commune; 36 meetings in Minh Hoang commune; 65 meetings in Cao Dai commune, and 203 meetings in Ngu Kien commune) with the local farmers to achieve the concurrence of all households for the final plan of land consolidation.

Traditionally, the farmers in the Red River Delta tend to retain their agricultural LURs because (1) households do not want to avoid fallowing land, even when they would like to quit working on their agricultural land; (2) the farmers are exempt from agricultural land tax (since 2003, meaning they do not have the motivation to transfer their LURs even when they do not keep agricultural production); and (3) typically, rural people consider their agricultural LURs as a means of insurance [62], which allows them to return to agricultural production at any time, especially when they cannot adapt to urban life or off-farm work. Therefore, these households prefer leasing out over transferring their land to relatives or acquaintances [63]. This process partly hinders the process of land consolidation toward large-scale agricultural production in the Red River Delta.

Additionally, it is not easy to manage informal land consolidation among individuals. In Phu Cu, in addition to $81 \%$ of the interviewed households having land parcels consolidated through the formal administrative procedure under the instruction of the local governments, $31 \%$ of the interviewed households still obtained some land parcels that were consolidated by self-negotiation. The percentage of households that have consolidated land by self-negotiation in Vinh Tuong was just 16\%, as the scale of land consolidation was smaller than that of Phu $\mathrm{Cu}$. In these cases, agricultural production was temporarily maintained but less sustainable for commodity production. Moreover, renting the duration of agricultural land causes difficulties in further land consolidation processes. Some households have consolidated land by renting 5\% communal land, with the longest term of only five years, or renting land from other households, with an average term of 3-5 years. They both complain about the short-term nature of renting land and feel hesitant about making long-term investments to improve the efficiency of cultivation.

Finally, all the households with mixed farms expressed the need to erect temporary buildings larger than $20 \mathrm{~m}^{2}$ to use to either store machines and agricultural tools or to house the people who take care of the farm. This construction is currently not authorized by the government.

\subsection{Land Consolidation Should be an Integrated Process of Multiple Policies}

Land consolidation is sometimes inadequately considered "reducing land fragmentation" [3], but this definition is inaccurate. Land consolidation must be understood as the integrated process of not only rearranging land parcels to larger fields but also adjusting road and drainage construction, crop conversion, labor transition, etc., towards the comprehensive development of rural areas. Accordingly, land consolidation in Vinh Tuong has not gained as many benefits as that in Phu Cu as, except for land parcel exchanges, other related policies have not yet been deployed. However, Vinh Tuong actually has more households that have been able to consolidate more than 1 ha in agricultural area per household (by self-negotiation) as many households here tend to rather find off-farm jobs.

Especially in Vinh Tuong, some farm households receive larger areas of land and larger parcels, but this land has lower-quality soil, which is not appropriate for rice cultivation. However, in some cases, they could not or have not yet been allowed to change the crop structure as the plan for crop conversion has not yet been approved. It is realized that the policies for planning and changing land use in agriculture must be adopted in association with the regrouping and rearranging land.

In $\mathrm{Phu} \mathrm{Cu}$, restructuring land parcels and related tools encourages farmers to participate in large-scale production and provokes the demand and supply of agricultural LURs in rural areas. Nonetheless, for joining agricultural commodity production and farm economics, local farmers must do their own research to find suitable plants for the local soil. Local authorities encourage either consolidating agricultural land or joining in farm economics and converting crops, but they do not have a formal and appropriate crop restructuring plan. At the beginning of the 2000s, in Nhat Quang commune, the local farmers tried to convert from growing paddies to planting lychee trees themselves 
and failed. After 1-2 years, they attempted to grow orange trees. They searched for seeds from various regions, learned the methodology of planting orange trees, and found the output market for their agricultural products, without close cooperation with outside researchers, agricultural cooperatives, and enterprises. Fruit prices are also not stable. In the early years of planting orange trees, the price of oranges could go up to 50 to 60 thousand VND per kg. However, recently, when more households are engaging in planting orange trees, the supply market has been gradually saturated, and the price in 2017-2018 dropped to only 20 to 35 thousand VND per kg. In addition, large-scale agricultural production requires a large amount of capital, modern technology, equipment, and highly qualified labor. However, most rural farmers cannot meet these requirements, while the state and local authorities cannot afford to provide specific support policies. Therefore, forming a strategic plan on agricultural land use conversion, finding a stable output market for agricultural products, and improving cooperation among stakeholders, including farmers, local authorities, enterprises, and scientists, have become compulsory policies to assure the efficiency of land consolidation toward agricultural commodity production.

\section{Conclusions}

The process of land consolidation in Hung Yen and Vinh Phuc is representative of that of the Red River Delta. The process significantly results in larger and contiguous fields in both provinces, though it is more pronounced in Hung Yen overall. Specific benefits from land consolidation on the economic, social, landscape, and soil environments are also recorded. These include opportunities to reduce fertilizer and pesticide costs, reductions in field traveling time, and increases in economic profits and the demand for seasonal laborers, etc. Almost all interviewed households expressed a positive attitude toward land consolidation activities. In all case studies, land consolidation should be continued.

However, land consolidation applied on a large scale faces several challenges caused by land fragmentation; traditional perceptions of farmers on small-scale agricultural production, policies, and the deployment of land consolidation in localities are still inadequate. To improve the efficiency of land consolidation, the government needs to improve the legal framework, improve accompanying policies, and provide integrated solutions to support and encourage the transfer and formal leasing of LURs. The market for practicing agricultural LURs (transfer, lease, mortgage, and capital contribution) should be built publicly and transparently according to the market mechanism, with simple administrative procedures. Additionally, concerns about vocational training and labor transition from agricultural production to nonagricultural activities, facilitating the investment capital by LURs, developing social insurance systems for farmers, etc., should be addressed. The provincial and district governments should make more strategic land use plans and orient the conversion in agricultural plants in detail to appropriately align with the characteristics of the consolidated land. Finally, other solutions to stimulate farm economics should be given more attention, based on strengthening cooperation among stakeholders, attracting enterprises to invest in rural agriculture, and encouraging the application of science and technology in agricultural production.

Author Contributions: Conceptualization, T.H.T.N. and T.Q.N.T.; data curation, Q.C.D.; investigation, T.H.T.N., V.T.T., T.P.P., Q.C.D., K.H.V., and H.G.D.; methodology, T.H.T.N. and V.T.T.; software, K.H.V.; supervision, T.Q.N.T.; writing-original draft, T.H.T.N., V.T.T., and T.P.P.; writing-review and editing, T.H.T.N., T.Q.N.T., V.T.T., T.P.P., and Q.T.B. All authors have read and agreed to the published version of the manuscript.

Funding: This research was funded by the national project “Nghiên cứu cơ sở khoa học, thực tiễn đề xuất mô hình sử dụng đất tập trung, quy mô lớn, hiệu quả, bền vững đáp ứng yêu cầu ứng dụng công nghệ cao trong sản xuất nông nghiệp tại các vùng kinh tế trọng điếm Việt Nam" (Researching scientific and practical bases to propose concentrated, large-scale, efficient, and sustainable land use models to meet the requirements of high-tech application in agricultural production in key economics regions of Vietnam), grant number BDKH.35/16-20".

Acknowledgments: We especially acknowledge the kind help of the People's Committee of Phu Cu district (Hung Yen province) and Vinh Tuong district (Vinh Phuc province), and the People's Committee of Nhat Quang commune, Minh Hoang commune (Phu Cu district), Cao Dai commune, Ngu Kien commune, Phu Thinh commune (Vinh Tuong district), and for providing us the necessary local socio-economic data and documents. We also 
would like to convey our thankfulness to the local people in these communes for accepting to join our household interviews and giving us initial information for the research.

Conflicts of Interest: The authors declare no conflict of interest.

\section{References}

1. Colombo, S.; Perujo-Villanueva, M. A practical method for the ex-ante evaluation of land consolidation initiatives: Fully connected parcels with the same value. Land Use Policy 2019, 81, 463-471. [CrossRef]

2. Jarosław, J.; Magdalena, Ł.; Ewa, J. Land Consolidation in Mountain Areas - Case Study from Southern Poland. Geod. Cartogr. 2017, 66, 241-251. [CrossRef]

3. Huu Quynh, N.; Peter, W. Land Consolidation as Technical Change: Impacts on-Farm and off-Farm in Rural Vietnam; ANU College of Asia and the Pacific: Canberra, Australia, 2018; p. 41.

4. Hiironen, J.; Riekkinen, K. Agricultural impacts and profitability of land consolidations. Land Use Policy 2016, 55, 309-317. [CrossRef]

5. Nilsson, P. The Role of Land Use Consolidation in Improving Crop Yields among Farm Households in Rwanda. J. Dev. Stud. 2019, 55, 1726-1740. [CrossRef]

6. Zeng, S.; Zhu, F.; Chen, F.; Yu, M.; Zhang, S.; Yang, Y. Assessing the Impacts of Land Consolidation on Agricultural Technical Efficiency of Producers: A Survey from Jiangsu Province, China. Sustainability 2018, 10, 2490. [CrossRef]

7. Pašakarnis, G.; Maliene, V. Towards sustainable rural development in Central and Eastern Europe: Applying land consolidation. Land Use Policy 2010, 27, 545-549. [CrossRef]

8. European Commission. Guidance Note C: Ex-Ante Evaluation Guidelines Including SEA. Communities; 566 Office for Officials Publications of the European Communities, Ed.; European Commission: Luxemburg, 2004.

9. OECD. Agricultural Policies in Vietnam; OECD: Paris, France, 2015; p. 239.

10. World Bank. Vietnam's Agricultural Growth: Increasing Value, Reducing Inputs; World Bank: Washington, DC, USA, 2016; p. 126.

11. World Bank. Transforming Vietnamese Agriculture: Gaining More for Less; World Bank: Washington, DC, USA, 2016; p. 126.

12. Anh Tuan, T. Institutional Analysis of the Comtemporary Land Consolidation in the Red River Delta: A Village-Level Study of Dong Long Commune in Tien Hai District, Thai Binh Province, Vietnam. J. Jimbunchiri 2006, 1, 20-39.

13. Thi Thu Thao, X.; Xuan Phuong, H.; Thi Lam Tra, H. Efficient use of farm land after the process of agricultural land accumulation in Nam Dinh province. J. Rural Dev. Agric. 2015, 19, 16-24.

14. Van Hung, P.; MacAulay, T.G.; Marsh, S.P. The Economics of Land Fragmentation in the North of Vietnam. Austral. J. Agric. Resour. Econ. 2007, 51, 195-211. [CrossRef]

15. Marsh, S.P.; MacAulay, T.G. Farm Size and Land Use Changes in Vietnam Following Land Reforms. In Proceedings of the the 47th Annual Conference of the Australian Agricultural and Resource Economics Society, Sydney, Australia, 12-14 February 2003; p. 34.

16. Quy-Toan, D.; Lyer, L. Land Rights and Economic Development: Evidence from Vietnam; World bank: Washington, DC, USA, 2003; p. 28.

17. FAO. The Design of Land Consolidation Pilot Projects in Central and Eastern Europe; FAO: Rome, UK, $2003 ;$ p. 55.

18. Jin, X.; Shao, Y.; Zhang, Z.; Resler Lynn, M.; Campbell James, B.; Chen, G.; Zhou, Y. The evaluation of land consolidation policy in improving agricultural productivity in China. Sci. Rep. 2017, 7, 2792. [CrossRef]

19. FAO. FAO's Land Tenure Service of the Rural Development Division. Available online: http://Fao.org (accessed on 4 November 2019).

20. Chunfa, W.; Jingyi, H.; Hao, Z.; Limin, Z.; Budiman, M.; Ben, P.M.; Alex, B.M. Spatial changes in soil chemical properties in an agricultural zone in southeastern China due to land consolidation. Soil Till. Res. 2019, 187, $152-160$.

21. Zahra, K.; Alireza, K. Land consolidation and its economic effects on the city district of Loutak_Zabol. Int. J. Econ. Res. 2012, 3, 53-60.

22. Tan, S.; Heerink, N.; Qu, F. Land fragmentation and its driving forces in China. Land Use Policy 2006, 23, 272-285. [CrossRef] 
23. Ciaian, P.; Guri, F.; Rajcaniova, M.; Drabik, D.; Paloma, S.G.Y. Land fragmentation and production diversification: A case study from rural Albania. Land Use Policy 2018, 76, 589-599. [CrossRef]

24. Crecente, R.; Alvarez, C.; Fra, U. Economic, social and environmental impact of land consolidation in Galicia. Land Use Policy 2002, 19, 135-147. [CrossRef]

25. Sayılan, H. Importance of Land Consolidation in the Sustainable Use of Turkey's Rural Land Resources. Procedia Soc. Behav. Sci. 2014, 120, 248-256. [CrossRef]

26. Guo, B.; Jin, X.; Yang, X.; Guan, X.; Lin, Y.; Zhou, Y. Determining the effects of land consolidation on the multifunctionlity of the cropland production system in China using a SPA-fuzzy assessment model. Eur. J. Agron. 2015, 63, 12-26. [CrossRef]

27. Asiama, K.; Bennett, R.; Zevenbergen, J. Towards Responsible Consolidation of Customary Lands: A Research Synthesis. Land 2019, 8, 161. [CrossRef]

28. Kathiresan, A. Farm Land Use Consolidation in Rwanda; Ministry of Agriculture and Animal Resources: Kigali, Rwanda, 2012; p. 45.

29. Borsellino, V.; Di Franco, C.; Schimmenti, E.; Asciuto, A.; Di Gesaro, M.; D’Acquisto, M. Land consolidation policies in Sicily and their effects on its farmland. Calit. -Acces La Succes 2014, 15, 79-85.

30. Phuc, T.; Mahanty, S.; Wells-Dang, A. From "Land to the Tiller" to the "New Landlords"? The Debate over Vietnam's Latest Land Reforms. Land 2019, 8, 120. [CrossRef]

31. The National Assembly of the Socialist Republic of Viet Nam. Land law 1993. 1993. Available online: https:/thuvienphapluat.vn/van-ban/Bat-dong-san/Luat-Dat-dai-1993-24-L-CTN-38481.aspx (accessed on 30 October 2019).

32. Secretariat of the Communist Party of Viet Nam. Resolution No. 06-BCT, Resolution on Some Issues of Agriculture and Rural Development. 1998. Available online: https://huvienphapluat.vn/van-ban/Linhvuc-khac/Nghi-quyet-06-NQ-TW-van-de-phat-trien-nong-nghiep-nong-thon-112629.aspx (accessed on 30 October 2019).

33. Prime Minister of the Socialist Republic of Viet Nam. Directive No 10/1998/CT-TTg Instruction for Strengthening and Completing the Lallocates Land, Granting Certificates of Right for Use of Agricultural Land. 1998. Available online: https://thuvienphapluat.vn/van-ban/Linh-vuc-khac/Nghi-quyet-06-NQ-TWvan-de-phat-trien-nong-nghiep-nong-thon-112629.aspx (accessed on 30 October 2019).

34. Prime Minister of the Socialist Republic of Viet Nam. Directive No. 18/1999/CT-TTg, On a Number of Measures to Promote the Grant of Certificates of Right to Use of Agricultural, Land in RURAL areas in 2000. 1999. Available online: https://thuvienphapluat.vn/van-ban/Bat-dong-san/Chi-thi-18-1999-CT-TTg-bienphap-day-manh-hoan-thanh-cap-giay-chung-nhan-quyen-su-dung-dat-nong-nghiep-dat-lam-nghiepdat-o-nong-thon-2000-45410.aspx (accessed on 30 October 2019).

35. Prime Minister of the Socialist Republic of Viet Nam. Resolution No. 03/2000/NQ-CP on Farm Economics. 2000. Available online: http://www.chinhphu.vn/portal/page/portal/chinhphu/hethongvanban?mode= detail\&document_id=7274 (accessed on 30 October 2019).

36. Prime Minister of the Socialist Republic of Viet Nam. Decision 80/2002/QD-TTg on Policy to Encourage Agricultural Products Consumption through Contract. 2002. Available online: https://thuvienphapluat.vn/van-ban/Linh-vuc-khac/Quyet-dinh-80-2002-QD-TTg-chinh-sachkhuyen-khich-tieu-thu-nong-san-hang-hoa-thong-qua-hop-dong-49655.aspx (accessed on 30 October 2019).

37. The National Assembly of the Socialist Republic of Viet Nam. Land law 2003. 2003. Available online: https:/thuvienphapluat.vn/van-ban/Bat-dong-san/Luat-Dat-dai-2003-13-2003-QH11-51685.aspx (accessed on 30 October 2019).

38. The Central Committee of the Communist Party of Viet Nam. Resolution No 26/NQ/TW7 on Agriculture, Farmers and Rural. 2008. Available online: https:/thuvienphapluat.vn/van-ban/Linh-vuc-khac/Nghi-quyet26-NQ-TW-nong-nghiep-nong-dan-nong-thon-69455.aspx (accessed on 30 October 2019).

39. Prime Minister of the Socialist Republic of Viet Nam. Decision 491/QD-TTg on the National Criteria for Building NEW countryside. 2009. Available online: https://thuvienphapluat.vn/van-ban/Van-hoa-Xa-hoi/ Quyet-dinh-491-QD-TTg-Bo-tieu-chi-quoc-gia-nong-thon-moi-87345.aspx (accessed on 31 May 2020).

40. Central Committee of the Communist Party of Viet Nam. Resolution No.19-NQ/TW the Sixth Conference, Central Committee of the Communist Party of Vietnam Course XI. 2012. Available online: https://huvienphapluat.vn/van-ban/Bat-dong-san/Nghi-quyet-19-NQ-TW-nam-2012-doi-moichinh-sach-phap-luat-ve-dat-dai-171705.aspx (accessed on 30 October 2019). 
41. Prime Minister of the Socialist Republic of Viet Nam. Decision 62/2013/QD-TTg on Encouraging the Development of Cooperation, Production LINKAGE with agricultural Product Consumption, and Forming Large Fields. 2013. Available online: https://huvienphapluat.vn/van-ban/Thuong-mai/Quyet-dinh-622013-QD-TTg-chinh-sach-khuyen-khich-phat-trien-hop-tac-lien-ket-san-xuat-211219.aspx (accessed on 1 November 2019).

42. The National Assembly of the Socialist Republic of Vietnam. Land law 2013. 2013. Available online: https://huvienphapluat.vn/van-ban/Bat-dong-san/Luat-dat-dai-2013-215836.aspx (accessed on 30 October 2019).

43. Prime Minister of the Socialist Republic of Viet Nam. Decree No. 98/2018/ND-CP Regarding Incentive Policy for Development of Linkages in Production and Consumption of Agricultural Products. 2018. Available online: https:/thuvienphapluat.vn/van-ban/thuong-mai/Nghi-dinh-98-2018-ND-CP-chinh-sach-khuyenkhich-phat-trien-hop-tac-san-xuat-san-pham-nong-nghiep-387110.aspx (accessed on 26 April 2020).

44. Ban chỉ đạo Tống điều tra Nông Thôn Nông Nghiệp và Thủy sản Trung Ương. Báo Cáo sơ bộ kết Quả Tống điều tra Nông Thôn, Nông Nghiệp và Thủy Sản Năm 2016 (Preliminary Report on the Results of the National Rural, Agricultural and Fishery Census); Statistical Publisher: Hanoi, Vietnam, 2016; p. 139.

45. Ministry of Agriculture and Rural Development. Circular 15/2014/BNNPTNT; Ministry of Agriculture and Rural Development: Hanoi, Vietnam, 2014.

46. Ministry of Natural Resources and Environment (MONRE). Tình Hình Tích tụ, tập Trung đất đai cho Phát Triến Nông Nghiệp: Phương Thức, mô Hình Thực Hiện và Các Giải Pháp (Concentrated Land Consolidation Situation for Agricultural Development, Modes, Implementation Models and Solutions); Ministry of Natural Resources and Environment: Hanoi, Vietnam, 2018.

47. Ban chỉ đạo tống điều tra dân số và nhà ở. Kết Quả Tống điều tra Dân số và nhà ở 2019 (Population and Housing Census 2019); United Nations Population Fund: New York, NY, USA, 2019; p. 127.

48. General Statistics Office of Vietnam. National Data Census. Available online: https://gso.gov.vn/ (accessed on 16 May 2020).

49. Huu Quang, T. Land accumulation in the Mekong Delta of Vietnam: A question revisited. Can. J. Dev. Stud. Rev. 2018, 39, 199-214. [CrossRef]

50. López Jerez, M. The rural transformation of the two rice bowls of Vietnam: The making of a new Asian miracle economy? Innov. Dev. 2019, 1-18. [CrossRef]

51. World Bank. Transforming Vietnam's Agriculture: Increasing Value, Reducing Inputs, Vietnam Development Report 2016; World Bank: Washington, DC, USA, 2016; p. 126.

52. Kim Chung, D. Land Accumulation and Concentration: Theoretical and Practical Fundamentals for Commodity Oriented Agricultural Development. Vietnam J. Agric. Sci. 2018, 16, 412-424.

53. People's Committee of Hung Yen Province. Báo Cáo Thống kê đấT đai Tỉnh Hưng Yên năm 2017 (Land Statistics Report of Hung Yen Province in 2017); People's Committee of Hung Yen Province: Thành phố Hưng Yên, Vietnam, 2018.

54. People's Committee of Hung Yen Province. Báo Cáo Tình Hình tập Trung, Tích tụ đất đai đế Phát triến sản xuất Nông Nghiẹp (Report on the Concentration and Accumulation of Land for Agricultural Production Development); People's Committee of Hung Yen Province: Thành phố Hưng Yên, Vietnam, 2017.

55. People's Committee of Vinh Phuc Province. Land Statistics Report of Vinh Phuc Province in 2017; People's Committee of Vinh Phuc Province: Thành phố Vĩnh Yên, Vietnam, 2018.

56. DERG; CIEM. Báo Cáo Phân Tích yếu tố ảnh Hưởng tới Phân Mảnh Ruộng đât và các tác động tại Việt Nam-Hỗ trợ Chương Trình Phát Triến Nông Nghiệp và Nông Thôn (Analytical Report on Factors Affecting Land Fragmentation and Impacts in Vietnam - Support for Agriculture and Rural Development Program) (ARD SPS) 2017-2013; NGO Resource Centre: Hanoi, Vietnam, 2014.

57. People's Committee of Vinh Phuc Province. Báo Cáo Tống kết Thực Hiện thi điếm Công tác dồn Thửa, đối ruộng 02 xã Cao Đại và Ngũ Kiên, huyện Vĩnh Tường, bài học Kinh Nghiệm, Nhiệm vu Thực hiện dồn thửa đối Ruộng trên địa bàn Tỉnh Vĩnh Phúc (Summary Report on Piloting Land Regrouping in Cao Dai and Ngu Kien Communes, Vinh Tuong District-Lessons Learned, Tasks of Land Regrouping in Vinh Phuc province; People's Committee of Vinh Phuc Province: Thành phố Vĩnh Yên, Vietnam, 2018.

58. People's Committee of Vinh Phuc Province. Plan for Implementing Land Consolidation in Agriculture in Vinh Phuc Province; People's Committee of Vinh Phuc Province: Thành phố Vĩnh Yên, Vietnam, 2018. 
59. People's Committee of Nhat Quang Commune. Báo Cáo Tống kết Việc ThựC Hiện dồn Thưa đối Ruộng đất Nông Nghiệp Giai đoạn 2013-2015 xã Nhật Quang (Summary Report on the Implementation of Agricultural Land Regrouping for the Period 2013-2015 Nhat Quang Commune); People's Committee of Nhat Quang Commune: Thành phố Hưng Yên, Vietnam, 2016.

60. People's Committee of Minh Hoang Commune. Báo Cáo Tống kết Thực Hiện dồn Thưa đối Ruộng xã Minh Hoàng năm 2013-2015 (Summary Report on Land Regrouping Implementation in Minh Hoang Commune in 2013-2015); People's Committee of Minh Hoang Commune: Thành phố Hưng Yên, Vietnam, 2016.

61. People's Committee of Phu Thinh Commune. Báo CáO Tống kết kết Quả Thực Hiện dồn Thửa, đối RuộNg Thôn Đan Phượg, xã Phú Thịnh (Summary Report on Results of Land Regrouping in Dan Phuong Village, Phu Thinh Commune); People's Committee of Phu Thinh Commune: Thành phố Vĩnh Yên, Vietnam, 2018.

62. Dinh Bong, N.; Van Dan, D.; Xuan Phuong, H. Pro-poor Policy Options/Vietnam: The Case for Land Consolidation Linked to Labor Transformation; Food and Agriculture Organization of the United Nations (FAO): Rome, Italy, 2008; p. 6.

63. Thi Minh Khue, N.; Thi Dien, N.; Thi Minh Chau, L.; Philippe, B.; Philippe, L. Leaving the Village but Not the Rice Field: Role of Female Migrants in Agricultural Production and Household Autonomy in Red River Delta, Vietnam. Soc. Sci. 2018, 7, 1-12.

(C) 2020 by the authors. Licensee MDPI, Basel, Switzerland. This article is an open access article distributed under the terms and conditions of the Creative Commons Attribution (CC BY) license (http://creativecommons.org/licenses/by/4.0/). 